\title{
Implantação do estado de Israel e a gênese dos conflitos israelo/árabes
}

\author{
Israel state implementation and the genesis of conflict Israeli/arab
}

\author{
Luciano Kneip Zucchi*
}

\section{RESUMO}

Objetivamos demonstrar principalmente, através da análise histórica e da política internacional, que a gênese dos conflitos no Oriente Médio, entre judeus e árabes, está inserida dentro de um contexto global e tem seu cerne em interesses imperialistas e também no bipolarismo surgido após a Segunda Guerra Mundial, e não em rivalidades ou ódios seculares entre povos, muito embora o discurso étnico/religioso tenha muitas vezes conseguido mascarar a realidade desse antagonismo, originário do século $\mathrm{XX}$, que adentrou o XXI sem perspectivas de resolução. A História demonstra que se, por um lado, judeus e árabes tiveram alguns "interins conflituosos", principalmente na aurora do Islã, por outro lado, conviveram pacificamente e produtivamente durante séculos, como no Califado Omíada da Espanha e em outras regiões. A proclamação do Estado de Israel em 1948, muito embora tenha se configurado numa solução de compromisso para o problema anti/semita no continente europeu, redundara, entretanto, e paradoxalmente, num novo estranhamento e em novos conflitos, agora entre judeus e árabes habitantes da Palestina e de todo o Oriente Médio. As potências europeias, nesse contexto, desaguam uma contradição que é sua no mesmo movimento em que reiteram seus preconceitos, transportando-os para - Médio Oriente e agravando o quadro sensivelmente com a Guerra Fria e o confronto entre Estados Unidos e União Soviética, que farão da região - rica em recursos energéticos imprescindíveis ao Ocidente - palco de seu enfrentamento, tornando pior uma situação que já era desesperada ao extremo.

Palavras-chave: Israel. Palestina. Sionismo. Oriente Médio.

\section{ABSTRACT}

We aimed to demonstrate mainly through historical analysis and international politics, the genesis of the conflict in the middle east between Jews and Arabs, is embedded within a global context and has its heart in imperialist interests and also the bipolarity emerged after the Second World War, and not in rivalry or hatred between secular people,

\footnotetext{
* Mestre em História Social pelo Programa de Pós-Graduação em História Social - Universidade Estadual de Londrina (UEL).
} 
although the ethnic/religious discourse has often succeeded mask the reality of this antagonism, originating in the twentieth century, which entered the Twenty First century with no prospect of resolution. History shows that, on the one hand, Jews and Arabs had some "conflicting interinsti", especially at the dawn of Islam, on the other hand, lived peacefully and productively for centuries, as the Umayyad caliphate in Spain and elsewhere. The proclamation of the State of Israel in 1948, although it had set up a compromise solution to the problem anti/Semitic in Europe, redound, however, and paradoxically, a new strangeness and new conflicts now between Jewish and Arab inhabitants of Palestine and throughout the Middle East. The European powers, in this context, flow into its contradiction that in the same motion that reiterated their prejudices, transporting them to the Middle East and, worsening noticeably with the Cold War and the confrontation between the United States and Soviet Union, which will make region - rich in essential energy resources to the West - the scene of their confrontation, making worse a situation was already desperate in the extreme.

Keyword: Israel. Palestine. Zionism. Middle East. 